\title{
Urdimento
}

Revista de Estudos em Artes Cênicas

E-ISSN: 2358.6958

\section{O processo criativo como espaço-fronteiriço matricial}

Odailso Sinvaldo Berte

\section{Para citar este artigo:}

BERTE, Odailso Sinvaldo. O processo criativo como espaço-fronteiriço matricial.

Urdimento,

Florianópolis, v. 2, n. 38, ago./set. 2020.

DOI: http:/dx.doi.org/10.5965/14145731023820200038

Este artigo passou pelo Plagiarism Detection Software | iThenticate 
O processo criativo como espaço-fronteiriço matricial

Odailso Sinvaldo Berte ${ }^{1}$

\section{Resumo}

Este estudo objetiva pensar o processo de criação artística como espaço-fronteiriço matricial. Ancorado na abordagem metodológica da bricolagem, analisa-se a criação da obra de dança performativa Tú, él, nosostros tres, inspirada em obras dos artistas mexicanos Frida Kahlo, Arturo Estrada e Nahum B. Zenil. Com isso, o processo criativo é entendido como espaço/útero modelado por interconexões e permeabilidades, gerador da obra de arte e capaz de recriar o/a próprio/a artista.

Palavras-chave: Processo criativo. Espaço-fronteiriço matricial. Dança performativa. Frida Kahlo.

\section{The creative process as a matrixial borderspace}

\section{Abstract}

This study aims to think about the artistic creation process as a matrixial borderspace. Anchored in the methodological approach of bricolage, the creation of the performative dance Tú, él, nosostros tres, inspired by works by Mexicans artists Frida Kahlo, Arturo Estrada and Nahum B. Zenil, is analyzed. Thus, the creative process is understood as a space/womb modeled by interconnections and permeabilities, which generates the work of art, and capable of recreating the artist himself.

Keywords: Creative process. Matrixial borderspace. Performative dance. Frida Kahlo.

\section{El proceso creativo como espacio-fronterizo matricial}

\section{Resumen}

Este estudio tiene como objetivo pensar en el proceso de creación artística como un espacio-fronterizo matricial. Anclado en el enfoque metodológico del bricolaje, analiza la creación de la obra de danza performativa Tú, él, nosostros tres, inspirada en obras de los artistas mexicanos Frida Kahlo, Arturo Estrada y Nahum B. Zenil. Con esto, el proceso creativo se entiende como un espacio/matriz modelado por interconexiones y permeabilidades, generando la obra de arte y capaz de recrear al artista mismo.

Palabras-clave: Proceso creativo. Espacio-fronterizo matricial. Danza performativa. Frida Kahlo.

Pós-Doutor em Arte pela Universidad Iberoamericana Ciudad de México. Doutor em Arte e Cultura Visual UFG. Mestre em Dança - UFBA. Especialista em Dança - FAP/UNESPAR. Licenciado em Filosofia - UPF. Professor do Curso de Dança-Licenciatura da UFSM. Coordenador do Laboratório Investigativo de Criações Contemporâneas em Dança (LICCDA). odailso.berte@ufsm.br 
O estudo que aqui compartilho é um recorte de uma pesquisa mais ampla intitulada El abrazo de amor de Kahlo, Estrada, Zenil y yo: una genealogía matrizal desde el cuerpo performativo (Berté, 2020), realizada em nível de Pós-Doutorado no Departamento de Arte da Universidad Iberoamericana Ciudad de México. Alicerçada em aportes do projeto feminista na arte, entre seus objetivos, a referida pesquisa visa: questionar a visão de que o envolvimento da dimensão política na criação artística é um ato estritamente masculino, ao passo que a dimensão pessoal seria uma vocação destinada às mulheres; fazer uma forma particular de uso e crítica das separações e objetificações do corpo (mulher, LGBT+, negro, indígena, com deficiência) manejadas pelo patriarcado; analisar o projeto artístico de Frida Kahlo, evidenciando a indissociável relação entre o pessoal e o político; refletir sobre a maneira como Arturo Estrada - aluno de Kahlo - canaliza o pessoal, o corpo e o feminino em seus processos criativos; compreender como Nahum Zenil - identificado com as sensibilidades de Kahlo - aprofunda a relação entre a autobiografia e a criação artística; e estudar os modos como as criações de Kahlo, Estrada e Zenil se entrelaçam aos meus processos criativos e impulsionam a proposição de uma dança performativa.

A pesquisa trata de evidenciar os encontros fronteiriços entre os processos criativos dos referidos artistas, construindo uma espécie de genealogia não como gráfico histórico ou árvore genealógica que identifica o DNA artístico ou a corrente discipular de Kahlo nesses artistas de maneira histórico-cronológica. Mas, em vez disso, uma compreensão da genealogia como espaço-fronteiriço matricial, uma rede copoiética construída por afetos, marcas, fios, vibrações e fascinações que impulsionam os processos criativos de uns artistas inspirados em outros. Nesse sentido, o foco está nos elementos estruturais das criações de Frida Kahlo que inspiram/impulsionam os processos criativos de Estrada, Zenil e os meus.

No presente texto, busco argumentar o processo criativo como espaçofronteiriço matricial e analiso o processo de criação da obra de dança performativa Tú, él, nosotros tres², feito a partir de obras dos artistas mexicanos Frida Kahlo

2 Esta obra faz parte de um conjunto de quatro obras de dança performativa criadas em minha pesquisa de pós-doutorado no Departamento de Arte da Universidad Iberoamericana Ciudad de México, no ano de 2018, sob orientação da Dra. Dina Comisarenco Mirkin. 
(1907-1954), Arturo Estrada (1925) e Nahum B. Zenil (1947). Entre as principais bases teóricas que referenciam este estudo estão as compreensões do espaçofronteiriço matricial, da artista e pesquisadora israelense Bracha Ettinger, e da criação como rede em processo, da pesquisadora brasileira Cecília Almeida Salles.

Para tal objetivo, uso da abordagem metodológica da bricolagem (Kincheloe; Berry, 2007), por suas características interdisciplinar, hermenêutica e de inovação epistemológica, usando conceitos de diferentes áreas para analisar o objeto de estudo em uma perspectiva multidirecional. A bricolagem considera a subjetividade do pesquisador e seus investimentos afetivos, entendendo seu papel na definição da pesquisa, no intuito de explorar a construção social do conhecimento, da percepção e da subjetividade humana. A partir das bases teóricas do campo de estudo da Cultura Visual, este texto estrutura-se com base "no uso social, afetivo e político-ideológico das imagens e nas práticas culturais que emergem do uso dessas imagens" (Tourinho; Martins, 2011, p. 53). Nesse sentido, trabalho artística e epistemologicamente na perspectiva da relação do sujeito (corpo, eu, experiência e autobiografia) com a imagem (obras de Kahlo, Estrada e Zenil) - relação esta atravessada pelo contexto sociocultural - para desenvolver o processo criativo. Conforme Salles (2017, p. 39), "o locus da criatividade" e, acrescento, da criação artística, "é pluralizado e historicizado", ou seja, o processo criativo interage com "intensas turbulências culturais" (Salles, 2017, p. 36), é favorecido pela “dialógica cultural.” (Salles, 2017, p. 37).

Destaco de antemão esses aspectos conceituais por eles serem, também, perspectivas metodológicas, modos de pensar-fazer a obra artística e a pesquisa sobre ela, já trazidos como pressupostos desde as escolhas procedimentais. Os afetos, marcas e fascinações que instauram o espaço-fronteiriço matricial, como será tratado a seguir, não acontecem num cenário sobrenatural, idealista ou puramente imaginário, mas no corpo-sujeito concreto que está em constante interação com o mundo e, portanto, com a cultura. Saliento ainda que as questões aqui desenvolvidas não abrangem a recepção da obra pelo público, pois isso mereceria uma pesquisa específica que ouvisse os espectadores para assim conhecer elementos de sua experiência estética com a obra. Detenho-me na 
minha experiência enquanto corpo-artista, enfatizando os modos como uso as imagens para a criação artística e reconhecendo como esse processo interfere na autobiografia recriando-me enquanto sujeito.

\section{Frida Kahlo: o enlace do pessoal com o social}

A crescente popularidade de Frida Kahlo tem desenvolvido uma espécie de ensimesmamento que despolitiza seu projeto artístico. Diferentes perspectivas biográficas, discursos curatoriais e produções da indústria cultural a tem visto como uma artista mulher atormentada por dores físicas e afetivas e pela impossibilidade de ser mãe, relegando sua trajetória a uma condição feminina sofrida, submissa e desequilibrada, suas obras a mero reflexo de seus traumas e tragédias sem grande valor estético, e seus processos criativos a uma espécie de recurso terapêutico. Na pesquisa da qual recorto o presente estudo, ao lançar mão do conceito de espaço-fronteiriço matricial, questiono essas visões que consideram Kahlo uma mulher estéril biológica e artisticamente, e enfatizo a fertilidade e a contundência da relação do pessoal com o político na sua (pro)criação, entendendo esta como geradora de referências, copoiesis, inspirações, afeições/afecções e fascinações nos processos criativos de outros artistas. Assim, construo uma genealogia matricial a partir de criações de Estrada, Zenil e eu, no sentido de pensar sobre a repetição que gera diferença, ou seja, as descobertas e invenções próprias desses artistas impulsionados por Kahlo.

Nos estudos de Ettinger (2006) sobre o espaço-fronteiriço matricial, se encontra um complexo arcabouço conceitual que entrelaça questões psicanalíticas (Jacques Lacan), filosóficas (Gilles Deleuze) e de gênero (Julia Kristeva e Judith Butler), entre outros/as. A autora investiga a matriz (útero, órgão feminino responsável pela gestação) transcendendo seu significado biológico/reprodutivo e apresentando-a como símbolo, como um espaço, uma esfera de coemergência, inter-relações, fascinação, transformações, criação e compartilhamento.

Questionando os modos freudianos, lacanianos e levinasianos de 
compreender a diferença sexual e a feminilidade, e propondo que a subjetividade não é limitada aos contornos de um corpo único mas entrelaçada por diferentes 'eus' e 'não-eus', Ettinger (2006, p. 189) argumenta que a "feminilidade [...] transforma, a partir de dentro, o que significa ser sujeito, pois é o núcleo do ser ético, a medida suprema do relacionamento ético”3. Em continuidade, a autora se refere ao feminino como "respons-abilidade matricial para com o outro", uma forma de "hospitalidade compassiva" (Ettinger , 2006, p. 189)4. Ancorada nas reflexões do projeto feminista na arte, Ettinger propõe uma perspectiva teórica, estética e política que possibilita refletir sobre a formação da subjetividade enlaçada com a alteridade, de maneiras distintas do olhar fálico do patriarcado que objetifica o outro. Suas proposições alentam as lutas feministas pela transformação das relações de gênero e lançam instigantes bases para repensarmos a arte, a relação artista/espectador e a criação artística - foco do presente estudo.

A "matriz", nesse sentido, "é um símbolo de subjetividades parciais coexistentes e coemergentes" (Pollock, 2000, p. 27), que tem uma forte significação corporal para as mulheres, no entanto, a matriz é um símbolo neutro que tem igual importância para reconstrução da subjetividade masculina para participa do espaço-fronteiriço matricial. E foi nesse sentido que se deu a escolha por refletir sobre a genealogia matricial de Frida Kahlo nos processos criativos de três homens (Estrada, Zenil e eu), no intuito de refletir sobre como os fios da matricialidade de Kahlo transcendem as tradicionais diferenciações sexuais e de gênero.

Localizando o pensamento de Ettinger (2005) na experiência estética, ou seja, na relação com as imagens e, dentre essas, a obra de arte, o "espaço-fronteiriço matricial" pode ser compreendido como uma "esfera psíquica que é transubjetiva", na qual ocorre o "encontro-evento matricial" - um acontecimento que transgride os limites individuais e invade as relações interpessoais instaurando diferentes

${ }^{3}$ Femininity [...] transforms from within what it means to be a subject, for it is the kernel of ethical being, the ultimate measure of the ethical relationship. (Tradução nossa)

${ }^{4}$ Matrixial response-ability to the other. [...] Compassionate hospitality. (Tradução nossa) 
campos de ressonância e formando uma "rede matricial" constituída por interconexões "corpo-psique-tempo-espaço" (Ettinger, 2005, p. 703-704). Na relação com a imagem/obra de arte ocorrem entrelaçamentos entre memórias (inclusive intrauterinas), afetos, traumas, fantasias e outras formas de experiências vividas que são evocadas, recordadas e associadas nessa interação.

A primeira vez que vi a obra Las dos Fridas (1939), o autorretrato duplo de Kahlo, em janeiro de 2016, no Museo de Arte Moderno, Cidade do México, emocionado, lembrei-me de minha mãe em seu vestido de noiva e na sua vestimenta de trabalhar no campo. Em um exercício mais acurado de percepção da obra, pensei nos modos de me ver e de ser visto pelos outros, e em como aquilo que sou conjuga, de certa forma, esse olhar interno e externo. Em um terceiro momento desse encontro-evento, lembrei de diferentes mulheres que conheço e que desdobram-se alternando diferentes funções (esposa, mãe, doméstica e outra profissão fora de casa). Após isso pensei sobre as experiências de vida que Kahlo pode ter usado como referências para realizar esta criação.

Las dos Fridas é uma das emblemáticas criações de Kahlo que nos possibilita especular sobre os enlaces fronteiriços entre a autobiografia e as questões socioculturais. Quando a pintora escreveu a Alfonso Manrique ${ }^{5}$, em 1939, para uma publicação na revista Hoy, explicando-lhe os sentidos que deu a essa obra, ela atribui o fato de ter pintado sua dupla imagem ao seu constante isolamento e busca de ajuda em si mesma, considerando-se sua melhor amiga. Isso se liga diretamente ao relato que ela escreveu em seu diário intitulado Origen de Las dos Fridas (Kahlo, 2017, p. 110-113) onde ela cria a imagem de uma amiga imaginária que era bailarina, que escutava e compreendia todos os seus problemas.

O fato de Kahlo pintar-se com traje europeu e indígena nesse duplo autorretrato também refere-se às suas práticas de vestir-se, nas quais usava diferentes acessórios e peças de roupas de diferentes povos indígenas mexicanos. Na passagem do século XVI para o século XX, o México era invadido pela cultura

${ }^{5}$ O fac-símile da carta de Frida Kahlo a Alfonso Manrique, escrita de Coyoacán, D.F., em 25 de outubro de 1939, foi consultado no livro La Casa Azul de Frida, coordenado por Frederico Rubli Kaiser, publicado por Chapa Ediciones, Ciudad de México, 2007, p. 47. (Tradução nossa) 
europeia, especialmente em decorrência da tentativa do presidente Porfirio Días ${ }^{6}$ em 'afrancesar' a sociedade mexicana. Enquanto as mulheres buscavam vestir-se como damas europeias (misturando costumes coloniais espanhóis e franceses), Frida Kahlo, esposa do notável muralista Diego Rivera, aparecia nos eventos sociais e políticos vestida de indígena, com suas peculiares sobrancelhas juntas, seu leve bigode e mancando. Essa deliberada posição político-performativa de Kahlo afrontava o embranquecimento eurocentrista da sociedade mexicana em sua época, na primeira metade do século XX, e isso aparece em muitas de suas pinturas, reforçando, pela dimensão artística, sua conduta pessoal e política ao mesmo tempo.

Outra fascinante criação de Kahlo na qual ela também mescla elementos políticos e pessoais, é o quadro Mi vestido cuelga ahí (1933-1938), que conheci na exposição Pinta la revolución: arte moderno mexicano 1910-1950, no museu do Palacio de Bellas Artes, Cidade do México, em julho de 2017. Nesse encontro com a obra, recordo da estranheza em ver a vestimenta de Frida vazia de seu corpo, perdida em meio à parafernália arquitetônica estadunidense. Ver o vestido de Kahlo exposto no centro do quadro, sobre as multidões das figuras recortadas e coladas, ainda me desperta uma imagem instigante:

[...] apesar do vestido estar vazio do corpo-Frida, é como se os corpos, as multidões estivessem saindo de dentro do vestido e povoando toda a base da imagem. Quase como um Cavalo de Tróia, do vestido proliferam numerosos corpos que ocupam as ruas e os espaços entre e na frente dos edifícios. É como se o corpo-Frida se disseminasse nos tantos corpos que preenchem todo o palco em frente a esse cenário de alta escala. No vão entre os prédios, ocupado desde o fundo pelas multidões, o vestido de Frida até lembra uma imponente alegoria sendo transportada numa parada, desfile ou manifestação, guiando a multidão. (Berté, 2018, p. 181).

O encontro-evento com esta obra de Kahlo, seja através da pintura original seja de uma imagem/reprodução desta (aqui não há juízo de valor entre arte e imagem) gera no corpo a fascinação. Para Ettinger (2005, p. 707) a "fascinação"

6 José de la Cruz Porfirio Díaz Mori (1830-1915), militar e político mexicano, foi presidente do México de 18761911. Seu governo ficou conhecido como porfiriato e ele foi destituído entre os eventos da Revolução mexicana (1910-1924). 
refere-se a "um afeto estético que opera na prolongação e no retraso do momento do encontro-evento"7 com uma obra de arte. A potencialidade transformadora da subjetividade, que caracteriza esse encontro-evento, afeta o corpo-sujeito pelo olhar, pela voz, pelo tato, pelo movimento e pela respiração. A duração estética da participação afetiva e efetiva do corpo-sujeito nesse encontro-evento, Ettinger chama de "fascinação".

Fascinado, me relaciono com os vários símbolos, ídolos, construções e monumentos característicos da cidade de Nova lorque e com o vestido de índia tehuana de Kahlo, nas cores verde, vermelho e branco, possível referência à bandeira mexicana, pendurado em uma corda presa em suas extremidades de um lado em vaso sanitário e de outro em um troféu, ambos suspensos por duas colunas gregas. As vestimentas de Kahlo conformam um conjunto de artefatos culturais que tem "capturado a imaginação pós-moderna na arte e na história da arte, ligadas como estão às questões do multiculturalismo, gênero e corporeidade" (Cordero, 2008, p. 146) ${ }^{8}$. O vestido de tehuana - parte por demais importante na performatividade de Frida Kahlo, que em seu cotidiano alternava seu uso com trajes masculinos - é um símbolo pátrio, imagem e distintivo identitário das matriarcas indígenas do Istmo de Tehuantepec que expressa a subjetividade feminina e a alteridade étnica e cultural.

Enquanto a arte mexicana pós-revolucionária, da primeira metade do século XX, exaltava o nacionalismo em grandes murais, Frida Kahlo pintava outras formas de nacionalidade, mexicanidade e identidade, em estreita conexão com sua autobiografia, criando assim, como observa Debroise (1991, p. 36, tradução nossa), "uma obra na contramão". Ao representar-se com atributos compreendidos como masculinos (Autorretrato con el pelo cortado, 1940), com atitudes consideradas perversas pela cultura e a moral (Dos desnudos en el bosque, 1939), como meninaadulta branca mamando no seio de uma mulher indígena (Mi nana y yo, 1937), entre outras obras, Kahlo instaura um modo criativo fronteiriço que enlaça elementos

${ }^{7}$ Fascinance is an aesthetic affect that operates in the prolongation and delaying of the time of encounterevent. (Tradução nossa)

8 [...] that has captured the postmodern imagination in art and art history, linked as it is to issues of multiculturalismo, gender, and corporety. (Tradução nossa) 
culturais, sociais e políticos à sua autobiografia. Embora muitos críticos de arte tentem classificar sua obra como surrealista, realista, popular, primitivista, naï, o caráter fronteiriço de seus processos criativos (tanto nos motivos quanto nos procedimentos) permite encontrar elementos dessas correntes/estilos em suas obras sem, no entanto, encaixá-la de maneira exclusiva em nenhuma delas.

A potência de espaço-fronteiriço do processo criativo de Frida Kahlo, que se diferencia do muralismo oficial precisamente por explicitar a indissociação entre o pessoal e o social, foi reconhecida pelo muralista Diego Rivera (2007, p. 233): "Colectivo-individual es el arte de Frida [...] pinta al mismo tiempo el exterior, el interior de sí misma y del mundo". Na sequência de seu texto, o muralista destaca Kahlo como um importante exemplo, na história da arte, de alguém que se desgarrou para dizer a "verdad biológica de lo que siente [...] poseída de la razónimaginación”. Esta sensível argumentação de Rivera, membro do muralismo oficial e conhecedor da obra de Kahlo, expressa, de maneira muito direta o caráter fronteiriço matricial das obras desta criadora. Trata-se de um entrelaçamento estético de sua subjetividade com sua sociabilidade, de sua autobiografia tramada pelos fios existenciais da relação corpo-mundo, um tipo de (pro)criação artística que traz desde as entranhas a fértil comunhão do eu-sujeito-Frida com sua história, sua cultura, sua gente, com o outro (não-eu). Em todo o conjunto de obras do projeto artístico de Kahlo é possível perceber o seu processo criativo como espaço-fronteiriço matricial que, na mescla do pessoal com o político, opera como uma cópula entre corpo e mundo.

No encontro-evento matricial com a obra de arte, as evocações, recordações e associações de memórias, fantasias, afetos, experiências vividas e projeções, podem se dar em diferentes direções, de acordo com a experiência culturalmente situada de cada corpo. A indissociabilidade corpo-psique-tempoespaço aqui é associada às compreensões de Greiner e Katz (2001) de que corpo e mundo estão constantemente trocando informações e "a cultura não seria uma oposição entre o externo e o interno" (Greiner e Katz , 2001, p. 68), mas "um sistema aberto, apto a contaminar o corpo e a ser por ele contaminado" (Greiner e Katz , 2001, p. 68, p. 73). O “corpo como processo de natureza e cultura, juntos" (Rengel, 
2008, p. 7), no qual não há separação entre os aspectos físicos, químicos, biológicos, emocionais e intelectuais, no encontro-evento com a obra de arte pode captar significados subsimbólicos que compõem a esfera matricial. Em sua capacidade transubjetiva e transafetiva, a arte possibilita um modo de conhecimento que, diferentemente do que é gerado/transmitido na/com a linguagem formal e sistemática, se dá através do compartilhamento de traços de desejos, traumas, memórias e fantasias entre o corpo-espectador e o corpoartista através do encontro-evento com a imagem/obra de arte.

De acordo com a proposição de Ettinger (2005, p. 707), percebo que no projeto artístico de Kahlo reside a capacidade de maternidade/outreidade "m/other" - que ressalta o princípio da alteridade e fundamenta a compreensão do espaço-fronteiriço matricial enquanto uma maneira outra de entender as relações socioculturais, interpessoais, de gênero, étnicas, e da criação e recepção da arte. Frida Kahlo é a $m$ /other que articula um projeto artístico perpassado pelo relação pessoal/político e, com este, inspira, fascina e move outros corpos-artistas em suas criações.

\section{Arturo Estrada: o momento histórico na criação artística}

No ano de 2018 conheci e entrevistei o pintor mexicano Arturo Estrada, aluno de Frida Kahlo e integrante do grupo conhecido como Los Fridos, junto de Fanny Rabel (1922-2008), Arturo García Bustos (1926-2017) e Guillermo Monroy (1924). Estes foram os alunos mais próximos da artista, de quando ela foi professora na Escuela Nacional de Pintura, Escultura y Grabado “La Esmeralda”, entre 1943 a 1945, na capital mexicana. Estrada desenvolveu sua formação artística no contexto da chamada arte pós-revolucionária, no qual o movimento muralista buscou resgatar os ideais da Revolução Mexicana, ocorrida entre 1910 e 1924.

Desde 1943 quando iniciou a dar aulas na Escuela La Esmeralda, as quais logo tiveram de ser transferidas para sua casa em Coyoacán por causa de sua saúde debilitada, Kahlo desenvolveu laços especiais de amizade e proximidade com Los Fridos que, mesmo depois de deixar oficialmente o cargo de docente em 1945, se 
estenderam até sua morte em 1954. Estrada conta que, como muitos dos artistas de sua época, entre eles os demais professores da escola, Kahlo era uma ardorosa mexicanista, empenhada em defender a identidade nacional mexicana enfatizando o acervo pré-hispânico, a figura indígena e os ideais revolucionários.

O amor ao México, a liberdade criativa, e a conexão entre criação artística e atuação sócio-política, compõem os principais ensinamentos de Kahlo a seus alunos. Visitas a sítios arqueológicos, igrejas, exposições, aos locais de trabalho dos muralistas da época, aos mercados, e o próprio jardim de sua casa onde dava aulas, povoado por animais, plantas nativas e esculturas pré-hispânicas, conformavam uma forma de ensino de arte que ia além das paredes da escola e estimulava as práticas de ver e a criação em contato com a vida. Estrada relata como Kahlo os estimulava:

\begin{abstract}
"Olhem que bonita se vê aquela figura, ali, comprando frutas. Olhem que bonito se vê este tecido pendurado". A maneira dela ensinar não era uma forma acadêmica muito estrita. Ela deixava que você mesmo fizesse o modelo, que você o interpretasse. E quando ela percebia que não sabíamos o que ver, o que esperar, então nesse momento ela intervinha: "Veja, é redondo, a luz vem do lado direito, é em partes que se vai dividindo o tom, primeiro bem forte, médio, e é sombra". Tudo foi no momento vivido, e é como realmente eu fui descobrindo a forma de ver, e fazer-me pintor. ${ }^{9}$
\end{abstract}

Estrada recorda a "Frida Kahlo entusiasta! Porque ela falava muito da função da pintura, não somente de fazer coisas bonitas, mas captar o momento histórico, desde o desenvolvimento do ser humano, a opressão, a miséria [...]"10. O entusiasmo de Kahlo e seu estímulo para seus alunos verem a cultura mexicana não de maneira exótica mas com atenção ao momento histórico, são fundamentos centrais nos processos criativos de Arturo Estrada. Em murais como Tríptico de la Independencia (1952) e Nuevo Laredo de ayer y hoy (1957), e em pinturas de cavalete como Mestizas (1960), Tierra (1962), Los Fridos (1985), Pintor inspirado (1997), e Antorcha campesina (2006), é possível perceber os modos como Estrada

\footnotetext{
${ }^{9}$ Entrevista de Arturo Estrada cedida a Odailso Sinvaldo Berte, em 30 maio 2018, Cidade do México.

${ }^{10}$ Entrevista de Arturo Estrada cedida a Odailso Sinvaldo Berte, em 30 maio 2018, Cidade do México.
} 
capta o momento histórico e plasma o concreto da vida e da cultura mexicana através de imagens do corpo, do feminino, da cultura pré-hispânica, da luta social, da dominação política, e do próprio ato da criação artística.

Conforme a crítica de arte Raquel Tibol (1961, p. 07), por "primitiva afinidade" Estrada elegeu Frida Kahlo talvez sem saber que isso "marcaria para sempre seu desenvolvimento estético":

A ninguno de los Fridos le fue tan fácil como a Estrada asimilar las claves y los cánones propuestos por la maestra; claves y cánones a los que él otorgó, intuitivamente, signos tales que le permitieron sumarlos, obteniendo por resultado un refinamiento popularista, que es lo más característico de su obra y su aporte al variado panorama de la pintura actual en México. (Tibol, 1961, p. 10).

Esta importante afirmação de Tibol auxilia a compreender os vínculos entre Estrada e Kahlo, os fios que tecem uma rede copoiética matricial entre esses dois artistas. A esfera matricial é transafetiva, ou seja, um campo de transferências e cotransformação-em-diferença que operam "em um movimento em espiral para romper repetições psíquicas eternas, inventando novas cordas e fios, e criando o que nos termos deleuzianos significa a diferença na repetição" (Ettinger, 2009, p. 23 - tradução nossa)11. Outro importante conceito para Ettinger é a "copoiésis" matricial. A partir da compreensão grega, poiesis significa criação, produção, ato de fazer, e tem fundamentado o conceito de estética e a compreensão dos processos criativos na arte. Ettinger (2005) propõe uma "copoiésis", que significa "a potencialidade criativa estética e ética dos enlaces fronteiriços [...]. Assim, um espaço-fronteiriço matricial é uma rede copoiética mutante na qual pode ocorrer a cocriatividade" (Ettinger , 2005, p. 705 - tradução nossa) $)^{12}$.

A copoiésis entre Kahlo e Estrada, ou seja, a potência criativa dos enlaces entre ambos pode ser percebida nas marcas dela no desenvolvimento artístico dele: as cores vibrantes, o sincretismo de estilos que bebem no realismo, no

11 in a spiralic movement for breaking psychic eternal repetitions and inventing new strings and threads, creating what in Deleuzian terms will stand for difference in repetition.

12 Copoiesis is the aesthetical and ethical creative potentiality of borderlinking [...]. Thus, a matrixial borderspace is a mutating copoietic net where co-creativity might occur. 
surrealismo e no primitivismo sem filiar-se a nenhum, a sagacidade popular e o uso de imagens. A perspectiva da copoiésis matricial impulsiona a criar e trilhar outras veredas escapando aos caminhos empedrados da arte. Em vez dos discursos sintáticos e semânticos sobre as obras, opto pela investigação dos processos e práticas criativas do corpo-artista para, a partir daí, configurar uma práxis - reflexão-ação - artística situada, capaz de produzir outros modos de conhecimento em arte, diferentes das elucubrações esteticistas e do olhar fálico do patriarcado que ainda insistem em determinar os regimes escópicos e a própria experiência estética.

Com a compreensão de uma rede copoiética matricial, olho para os modos como Frida Kahlo coparticipa das criações de Estrada, gerando uma espécie de cocriação que interpela as fronteiras individuais das compreensões do artista como gênio isolado. O compartilhamento, a permeabilidade e a alteridade - o reconhecimento do outro no eu - que caracterizam a copoiésis matricial rompem a bolha da identidade própria do sujeito, enfatizando que o artista pode ser compreendido como uma espécie de "multiplicidade sem fim, comunidade coletiva e sociedade organizada" (Ettinger, 2005, p. 704 - tradução nossa)13, uma trama corpo-psique-espaço-tempo atravessada por outros corpos-psiquesespaços-tempos e (trans)formado por inúmeras imagens.

Em sua obra intitulada La columna (1987), Estrada manifesta um instigante exercício criador baseado no uso de imagens de seu próprio repertorio artístico e em imagens de Frida Kahlo.

${ }^{13}[. .$.$] multiplicity, collective community and organized society.$ 
Figura 1 - Arturo Estrada, La columna, 1987, pintura sobre cartão e collage, 50 × 63 cm, Coleção privada

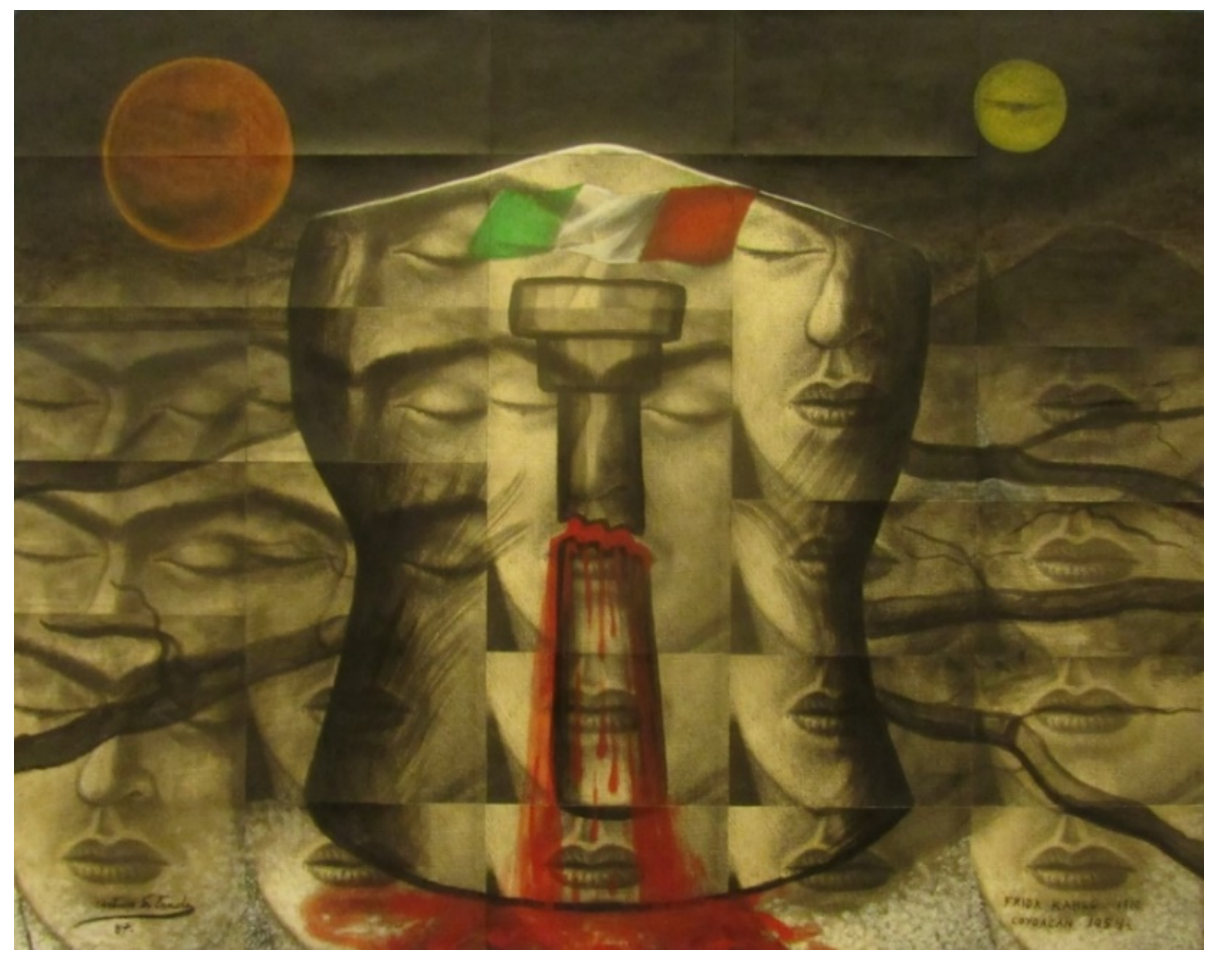

Fonte: Arquivo de Odailso Sinvaldo Berte

Em La columna (Figura 1) Estrada recria o corsé de Frida com a coluna grega partida. Frente a esta obra perguntei-lhe: Por que você escolheu a coluna de Frida para pintar? E de maneira cálida Estrada buscou no seu estúdio, onde estávamos, algumas pastas com imagens - reproduções de obras suas, de Diego Rivera, e de Frida Kahlo. Dentre as de Kahlo ele tirou as imagens das obras Árbol de la esperanza mantente firme (1946) e La columna rota (1944), e disse:

Uma vez fomos ao seu estúdio e ela nos permitiu entrar, mas isso não era muito comum. E aí vimos o quadro da coluna, e ela estava nua. Passado um tempo, lhe perguntamos: Maestra, o que está pintando? 'Acabo de pintar o quadro da coluna', disse ela. E ao mostrar-nos o quadro, vimos que ela havia coberto seu genital. Maestra, mas o que aconteceu? Por que cobriu-se? lhe perguntamos. Ela havia coberto o nu aqui abaixo da coluna. E ela disse: 'Não, é que o tema não é o sexo, é a coluna'. Assim, muito precisa: o tema é a coluna. Por isso me ocorreu pintar nesta tela o corsé que ela tanto usava. ${ }^{14}$

\footnotetext{
${ }^{14}$ Entrevista de Arturo Estrada cedida a Odailso Sinvaldo Berte, em 30 maio 2018, Cidade do México.
} 
Esta fascinante experiência vivida junto com sua professora e encontroevento com a obra La columna rota, serviu de inspiração para Estrada criar sua obra La columna. Nesta obra ele faz um especial uso de imagens plasmando um enlace-fronteiriço entre sua própria obra Vida - Muerte de Frida Kahlo (1954) - o único retrato pintado de Frida Kahlo morta em seu caixão -, e as obras Árbol de la esperanza mantente firme (1946), La columna rota (1944) e o Corsé la columna rota(1944), de Kahlo. O solo rachado do Pedregal de Coyoacán, o mesmo que Kahlo pintou em Árbol de la esperanza mantente firme e La columna rota. Estrada o recria coberto com o rosto de Frida morta através da técnica da collage com várias fotografias em preto e branco de sua obra Vida - Muerte de Frida Kahlo.

Em La columna, obra criada no 33a ano da morte de sua professora, Estrada externa, de maneira concreta, a copoiésis matricial entre sua obra e a de Frida Kahlo. A retomada e a reconstrução das imagens de Kahlo e os afetos da experiência vivida com ela, mesclados com elementos de seu próprio repertorio, dão movimento vital à esfera matricial que o enreda à sua maestra. Estrada não só recorda e celebra sua professora e os aprendizados com ela, como também faz da obra um demarcador do momento histórico em que vive, onde iniciavamse os movimentos de resgate da obra e da própria imagem de Frida Kahlo.

A década de 1980 é o cenário dessa redescoberta de Kahlo, em que surgem obras visuais, cinematográficas, teatrais, performáticas, musicais e literárias, entre elas o filme Frida, naturaleza viva (1983) de Paul Leduc, a exposição de Frida Kahlo e da fotógrafa Tina Modotti (1983), a primeira biografia, escrita por Hayden Herrera, Frida: una biografia de Frida Kahlo (1985), e pinturas de artistas neomexicanistas que inspiraram-se nos temas e imagens de Kahlo, como tratarei a seguir. Estrada, que conviveu e conheceu bem de perto Frida Kahlo, atento às visões e interpretações um tanto psicologistas, personalistas, docilizadas e despolitizadas que surgiam sobre sua professora, plasma nessa obra a dor corporal, o solo ressecado onde ela pisou, a bandeira mexicana que ela tanto honrou, reclamando, de certa forma, a Frida concreta que vinha sendo preterida em função de uma Frida glamorizada.

Para além dessa e outras obras que trazem a referência visual direta de 
Kahlo, todo o projeto artístico de Estrada é marcado pelo amor à cultura mexicana, o compromisso social e político, a atenção ao momento histórico, o sincretismo de estilos e técnicas, e a mescla disso com elementos autobiográficos, traços fundamentais herdados de Kahlo. Destaco isso pois a copoiésis matricial não se tece apenas por evidencias visuais, mas por visualidades fronteiriças, remanescentes subsimbólicos para além da aparência representativa.

\section{Nahum B. Zenil: corpo e sexualidade}

No final da década de 1970, especialmente a partir das criações do pintor Enrique Guzmán (1952-1986), uma prática artística de grande força política e sociocultural surgiu no contexto artístico mexicano e ficou conhecida como Neomexicanismo. Assim foi chamada por sua característica de resgate de certas constantes da identidade mexicana, aparentemente semelhante aos propósitos mexicanistas do período da arte pós-revolucionária, mas que, em vez da abordagem nacionalista, instaurou uma perspectiva refuncionalizadora, paródica, irônica e crítica no trato dos símbolos nacionais, religiosos e populares. Entre os criadores neomexicanistas ocorreu uma espécie de resgate de Frida Kahlo, tanto de sua perspectiva estética como de sua própria imagem, como se ela, menos de trinta anos após sua morte, já fosse parte do grande acervo cultural de imagens mexicanas.

É possível identificar como Nahum B. Zenil, Julio Galán, Javier de la Garza, Lucía Maya, Georgina Quintana, Rocío Maldonado e Dulce María Núñez retomam Frida Kahlo em suas criações seja de maneira direta ou fronteiriça, pelos modos como elas e eles plasmam na criação sua relação com o contexto, a política, a subjetividade, a sexualidade, o corpo, e as questões de gênero. Isso tanto pode ser visto como uma oposição ou como um desdobramento e avanço nos ideais da arte pós-revolucionária. As/os neomexicanistas, através de Frida Kahlo, buscam expressar e dar visibilidade aos sujeitos emergentes, às identidades antes opacadas pelos discursos socialistas coletivistas com seus termos chave "massa", "povo", "nação". O neomexicanismo é um resgate estético e crítico do mexicanismo 
da primeira metade do século XX que especifica e localiza as individualidades na relação com as tradições cívicas, religiosas, populares, propondo diferentes formas de luta pela transformação social.

Conforme Eckmann (2011, p. 141):

En los años setenta, cuando los artistas neomexicanistas estudiaban en La Esmeralda y se vivían los movimientos por los derechos estudiantiles, feministas y homosexuales, Kahlo se ubicaba en la periferia, no era reconocida en México como es ahora [...] Y por serlo, la fuerza y la alteridad de Kahlo resultaban atractivas para otros que se veían a sí mismos en los márgenes, en particular las mujeres y los hombres homosexuales.

Nesse contexto sociocultural, Nahum B. Zenil, que também estudou na Escuela La Esmeralda entre 1968 a 1972, desenvolveu seu projeto artístico centrado no corpo, na sexualidade e na autobiografia, utilizando dos seus afetos, de suas experiências, e da autoimagem, relacionados com diferentes símbolos cívicos, culturais, populares e religiosos. Reconhecido entre os movimentos de luta pelos direitos LGBT+, no México e em outros países, como artista queer, Zenil plasma abertamente em suas criações a sua intimidade, a relação com seu cônjuge Gerardo Vilchis, seus desejos, medos, memórias e seu corpo nu entre imagens da Virgem de Guadalupe, Cristo crucificado, Frida Kahlo, a bandeira mexicana, corações sangrentos, as cartas da loteria mexicana, e sua terra natal, a localidade de Tecomate, município de Chicontepec, no estado de Veracruz.

Obras como San Sebastián (1983), Lucha de Jacob y el Ángel (1985), Sin título (Frida y el diablo) (1985), Frida de mi corazón (1991), Frida y yo (1993), Hombre tatuado (1998), Soy puro mexicano (1989), Asiento privado (1990), Siéntate conconfianza (1990), El abrazo (2002), Los amantes de los volcanes (2017), expressam o amor homoafetivo, o pânico do alastramento da Aids no mundo e a mácula que recaiu sobre os gays, a importância do sexo seguro, a pátria mexicana e seus símbolos nacionalistas machistas. Em seu projeto artístico, Zenil enlaça seu corpo e sua sexualidade com símbolos religiosos, populares, cívicos e artísticos, manifestando uma pungente prática artística sensibilizadora e provocadora, ao 
mesmo tempo.

Por estas características, Raquel Tibol identificou nas criações de Zenil uma pungente vinculação com a obra de Frida Kahlo. Em um exemplar de seu livro Frida Kahlo: crónica, testimonios y aproximaciones, de 1977 (obra pioneira nos estudos sobre Kahlo) o qual autografou e presenteou a Zenil, Tibol afirmou o seguinte: "Querido Nahum, nestas páginas há um mundo em comum ao seu, digo isso com carinho. Raquel Tibol. 12 julho 78."15 Sobre esta compreensão de Tibol, Zenil diz que:

Isso foi casualidade. Porque quando eu conheci Raquel Tibol e ela me entrevistou pela primeira vez [...], e me deu de presente o primeiro livro que escreveu sobre Frida, pôs nele uma dedicatória que me impressionou. Eu não havia reparado na semelhança da obra de Frida com a minha, nem sequer havia pensado sobre isso. Mas ela me fez ver que havia certa semelhança na temática, a ideia do autorretrato, da autobiografia. E a partir desse momento, vi a obra de Frida e com propósito comecei a tomar elementos de suas obras e o seu próprio retrato como elementos para minha obra. ${ }^{16}$

Consciente da família de sensibilidades que o vincula a Kahlo, Zenil passa a tecer sua identificação com ela de modo mais sistemático em seu trabalho, através do uso, jogo, e recontextualização das imagens dela que o inspiram. Relacionando a proposição da copoiésis de Ettinger com as compreensões de Salles, quando esta trata da "criação como rede" (Salles, 2017, p. 36), penso a rede copoiética que enlaça os diferentes elementos dos processos criativos de Kahlo, Estrada e Zenil, possibilitando que estes sejam vistos como espaços-fronteiriços matriciais. A rede de interações de Zenil é marcada pela multiplicidade cultural que conforma seu corpo-psique-tempo-espaço. Zenil, suas criações e seu mundo em comum com Kahlo conformam uma espécie de comunidade com constituição cultural e situação espacial, temporal e histórica. Ainda que as obras de Zenil tragam as marcas da sua singularidade autoral, com Salles (2006, p. 153)

15 "Querido Nahum, en estas páginas hay un mundo en común al suyo, se lo digo con cariño. Raquel Tibol. 12 julio 78. O exemplar dado pela crítica de arte Raquel Tibol a Nahum B. Zenil, contendo esta dedicatória escrita com caneta de cor vermelha, foi consultado na biblioteca particular do artista em sua casa-museu Rancho Tecomate Cuatolco, na cidade de Tenango del Aire, estado de México, em março de 2018.

${ }^{16}$ Entrevista de Nahum B. Zenil cedida a Odailso Sinvaldo Berte, em 29 jan. 2018, Tenango del Aire, estado do México. 
compreendo "a criação como um processo de inferências [...], um processo de transformação que envolve uma grande diversidade de mediações". A criação de Zenil, e também de Estrada, é uma combinatória de experiências matizada por múltiplas conexões, autobiografia, atenção ao momento histórico, fascinações, afecções e familiaridades com Kahlo que dificultam determinar o ponto inicial dessa rede copoiética.

Em 1983 a crítica de arte Teresa del Conde organizou, no Museo Carrillo Gil, da Cidade do México, uma exposição chamada Paráfrasis. Zenil comenta que para esta ocasião the ocorreu fazer a obra Con todo respeto (1983): "Desenho aí uma de Las dos Fridas, sentada em um vagão do metrô [...]; as personagens que a acompanham são pessoas muito achegadas a mim, Gerardo, minha mãe, meu tio que estava convalescente, e duas crianças como o futuro do país. ${ }^{17}$

Figura 2 - Nahum B. Zenil, Con todo respeto, 1983, técnica mista sobre papel, 30,5 × 41 cm. Foto: Odailso Sinvaldo Berte

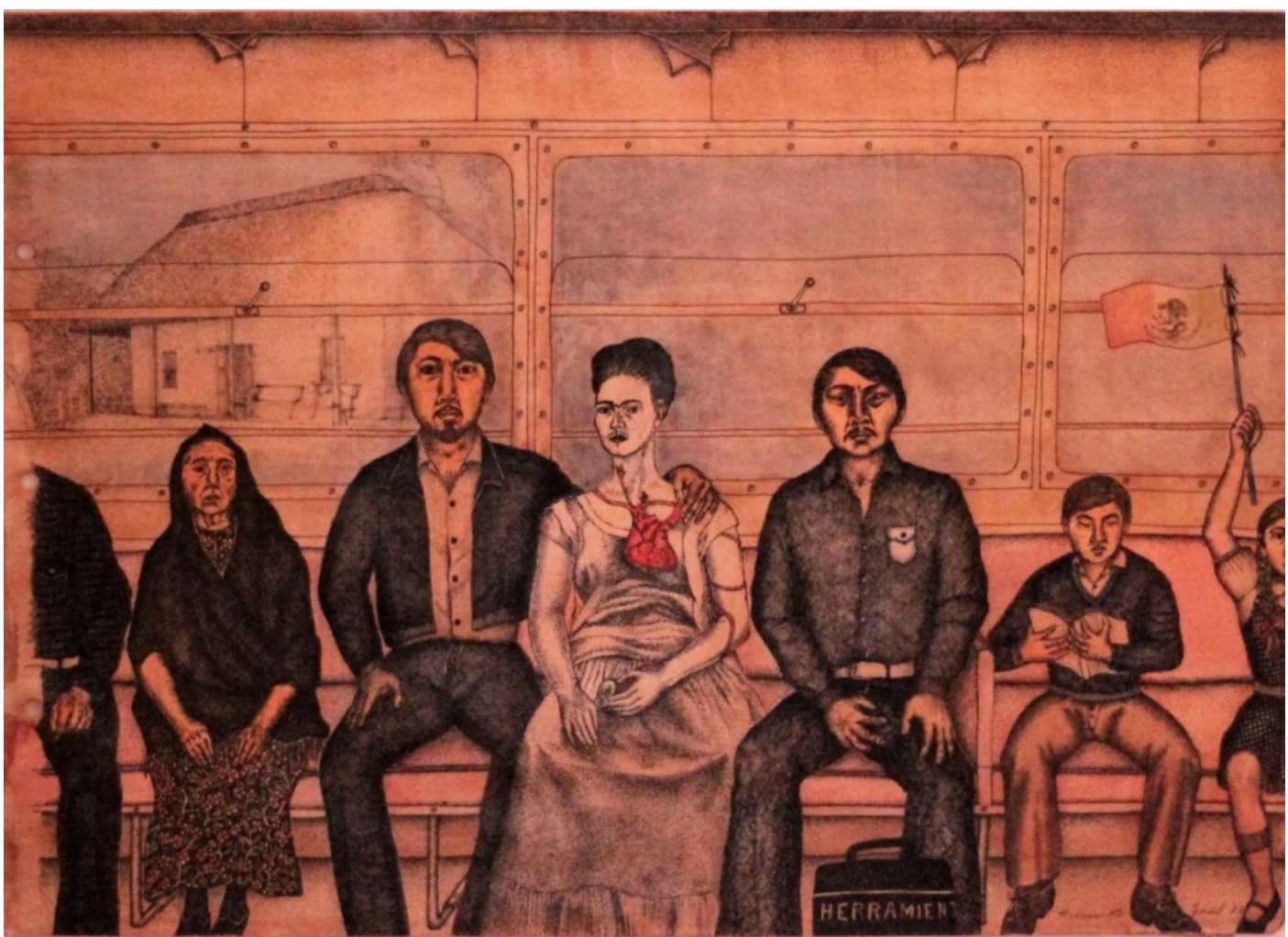

Coleção do artista

${ }^{17}$ Entrevista de Nahum B. Zenil cedida a Odailso Sinvaldo Berte, em 29 jan. 2018, Tenango del Aire, estado do México. 
Com suas táticas de usar e refuncionalizar imagens do acervo cultural à sua disposição, e relacionando-as com sua própria imagem, Zenil estabelece um encontro-evento matricial com as obras El camión (1929) e a icônica imagem dupla de Kahlo em Las dos Fridas (1939). A partir da fascinação gerada nesse encontro ele cria a obra Con todo respeto (Figura 2), na qual aparece sentado ao lado de Kahlo, abraçando-a, formando uma imagem que bem pode simbolizar o enlace matricial, a familiaridade de sensibilidades entre ambos. A imagem de Kahlo tem uma coloração branca, distinta dos outros personagens, como um fantasma, uma presença dolorosa e inspiradora que expõe seu vermelho coração sangrando. Zenil e Kahlo não estão separados do mundo, mas em um vagão do metrô, e como na obra El camión de Kahlo, estão acompanhados de mais pessoas da família de Zenil e as duas crianças que trazem à mão um livro e uma pequena bandeira mexicana. Através da janela do metrô se vê o rancho onde Zenil viveu sua infância, em Tecomate.

As alusões à sexualidade nesta obra, aparecem nas figuras de Gerardo, que está agarrando seus genitais, na protuberância dos genitais de Zenil e do menino, e na própria Frida que segura o pequeno retrato com a mão sobre a região genital. Essa referência sexual é uma constante nas obras de Zenil, especialmente nas que os corpos não estão nus. Nessa obra, Zenil se identifica, se inspira, se apropria e transforma as imagens de Kahlo em uma obra completamente sua, com sua técnica, suas questões afetivo-sexuais, seus temas e propósitos.

Com Kahlo, Zenil desenvolve uma rede copoiética, uma cocriação em rede na qual o autorretrato mesclado com questões políticas e socioculturais torna-se uma forma de visibilizar as subjetividades opacadas e silenciadas, de explicitar o valor da alteridade e da diversidade. A técnica do desenho figurativo e da coloração amarelada, ele busca em fotografias e cartões antigos, com o propósito de trazer um aspecto saudoso e melancólico para suas obras. Com imagens de Kahlo e como ela também procedia, Zenil ama, valoriza, ironiza e utiliza do acervo cultural mexicano, evidenciando o corpo e as outras sexualidades legítimas que se diferenciam da heteronormatividade. A familiaridade de sensibilidades e o mundo em comum entre ambos sustentam as tramas corpo-psique-espaço-tempo que 
enlaçam Zenil à rede copoiética matricial de Frida Kahlo.

\section{Tú, él, nosotros três}

Entrelaçando pesquisa e criação, a obra de dança performativa Tú, él, nosotros tres $^{18}$ foi criada no seio do estudo sobre o espaço-fronteiriço matricial e dos enlaces entre Kahlo, Estrada, Zenil e eu, servindo como movimento-reflexão que potencializa a indissociabilidade teoria e prática sustentadora da pesquisa. Uma de minhas buscas nesse processo foi compreender esse trabalho artístico como dança performativa, ou seja, uma espécie de obra performática alicerçada no movimento e na ação, tendo por base criadora a relação do corpo com a imagem. Isso decorre de estudos anteriores em que fundamentado em estudos do corpo, da Cultura Visual, das neurociências e outras áreas, tenho pensado a imagem como artefato, ideia e ação corporal em processos de criação artística (Berté, 2015).

O processo criativo de Tú, él, nosotros tres partiu da obra El jugador (2003), de Zenil, um autorretrato no qual ele mescla seu corpo com as cartas do jogo popular da loteria mexicana, como se fosse constituído por essas imagens. Motivado por essa obra, selecionei algumas das cartas da loteria mexicana associando-as com obras de Kahlo, Estrada e Zenil para, nessa associação de imagens, criar os movimentos e ações que estruturaram a referida dança performativa.

A carta 48 - La Chalupa, relacionei com as obras Autorretrato con listón rojo (1940), La columna rota (1944) de Kahlo, La columna (1987) de Estrada e Con todo respeto (1983) de Zenil. A carta 27 - El Corazón, com Las dos Fridas (1939) de Kahlo, Ex Voto (1987), Frida de mi corazón (1991) e Mírate en este espejo (1997) de Zenil. E assim foram feitas outras associações.

18 Ficha técnica da obra de dança performativa Tú, él, nosotros tres. Criação, direção, performance e figurino: Odailso Berté. Curadoria: Liz Katherine Maldonado Macías. Ano de criação: 2018. País de criação: México. Música: Felicidade (Suba/Juryman mix). 
Figura 3 - Loteria mexicana carta 28 - El Corazón; Nahum B. Zenil, Frida de mi corazón (1991) e Ex Voto (1987)

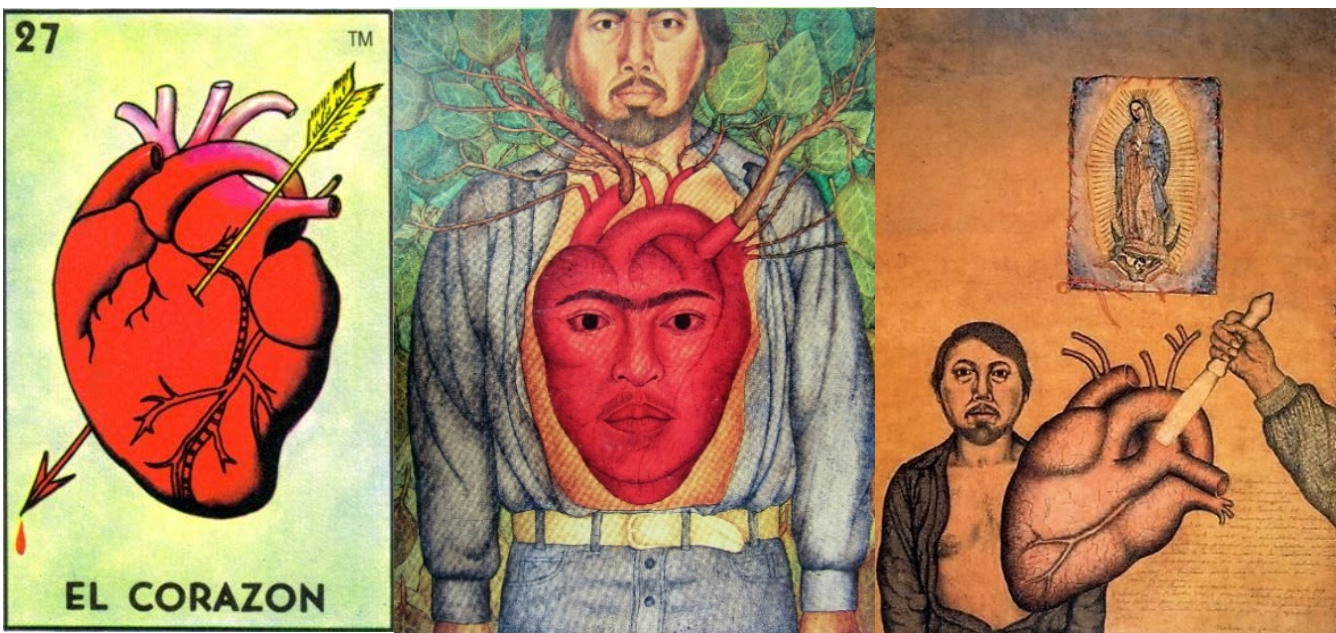

Arquivo de Odailso Sinvaldo Berte

Estas associações entre as cartas da loteria mexicana e as obras de arte foram feitas de acordo com as proposições do campo de estudos da Cultura Visual que "rechaça distinções entre cultura superior e inferior que privilegiam o estudo de objetos reconhecidos como parte integrante das belas artes" e "trata as imagens - de arte, de informação, de publicidade, ficção, entretenimento - sem hierarquiza-las" (Martins; Sérvio, 2012, p. 138-139). Nesse sentido, o foco aqui não é a análise semântica e sintática tanto das imagens como da obra de dança performativa, mas a experiência sociocultural e afetiva - o encontro-evento matricial - do corpo-sujeito-artista com as imagens para desenvolver a criação artística, conformando uma rede copoiética com os demais criadores (Kahlo, Estrada e Zenil) e percebendo como estes artefatos culturais (as imagens) interferem na sua subjetividade, recriando-o nesse processo.

As associações foram feitas a partir das proximidades entre os símbolos que compõem essas imagens, por exemplo, La Chalupa traz a imagem de uma mulher vestida com roupas típicas mexicanas remando em uma canoa cheia de flores e frutas, a qual relacionei com a efígie de Frida Kahlo, seu característico penteado (Autorretrato con listón rojo, 1940), seu corsé e sua coluna machucada (La columna rota, 1944). Cada grupo de imagens, representados pela respectiva carta, inspirou a criação de um conjunto específico de movimentos e ações. O título Tú, él, 
nosotros tres é uma frase que Zenil repete constantemente em diferentes obras de seu repertório de poesias, e neste trabalho quer referir a copoiésis, o enlace matricial entre Kahlo, Estrada, Zenil e eu nesta criação.

Neste processo criativo de dança performativa, a imagem é compreendida como momento e/ou como atmosfera. Como momento, a imagem determina de maneira visível um ou mais momentos específicos da sequência de movimentos, aparecendo quase que plasticamente no corpo-artista. Por exemplo, se pensamos uma sequência de movimentos constituída por três momentos, começo, meio e fim, a imagem funciona como se fosse uma foto que suspende/congela um desses momentos - o meio - motivando a criação dos movimentos/ações que são o seu antes e o seu depois. Como atmosfera, a imagem não aparece visivelmente no movimento/ação, mas é internalizada pelo corpo motivando os estados psíquicos que ele transforma em movimentos. Na sequência de movimentos instaura-se então uma atmosfera motivada pela imagem.

Entre os objetivos de Tú, él, nosotros tres está o meu desejo, enquanto criador, de transformar as imagens em movimento para compartilhar com o público o encontro-evento matricial que estabeleci com essas imagens de Kahlo, Estrada, Zenil e da loteria mexicana. E, talvez, antes disso, sentir e explorar os enlaces matriciais entre esses artistas e eu relacionando-os com elementos de minha história de vida e produzindo não uma obra/objeto externa a mim, mas em mim, no corpo. Investigar a possibilidade de uma dança performativa nos entrecruzamentos entre dança contemporânea e performance, corpo e imagem. Como consequência, (embora eu não tenha o alcance disso sem ouvir os sujeitosespectadores), provocar no público questionamentos acerca das questões de gênero, desconcertar a imagens/visões de homem e mulher, hétero e homossexualidade. E ainda, despertar o senso de que a arte, a exemplo de Kahlo, Estrada, Zenil, e coreógrafos como Pina Bausch (1940-2009), Johann Kresnik (1939), entre outros, ao expressar questões pessoais, tem implicâncias sociais, ou seja, (est)éticas, que transcendem as questões de gosto e as fronteiras individuais, enlaçando histórias de vida e seus contextos historicizados na trama corpopsique-tempo-espaço. 
Figuras 4 e 5 - Tú, él, nosotros tres, 2018, Galería José María Velasco, Cidade do México
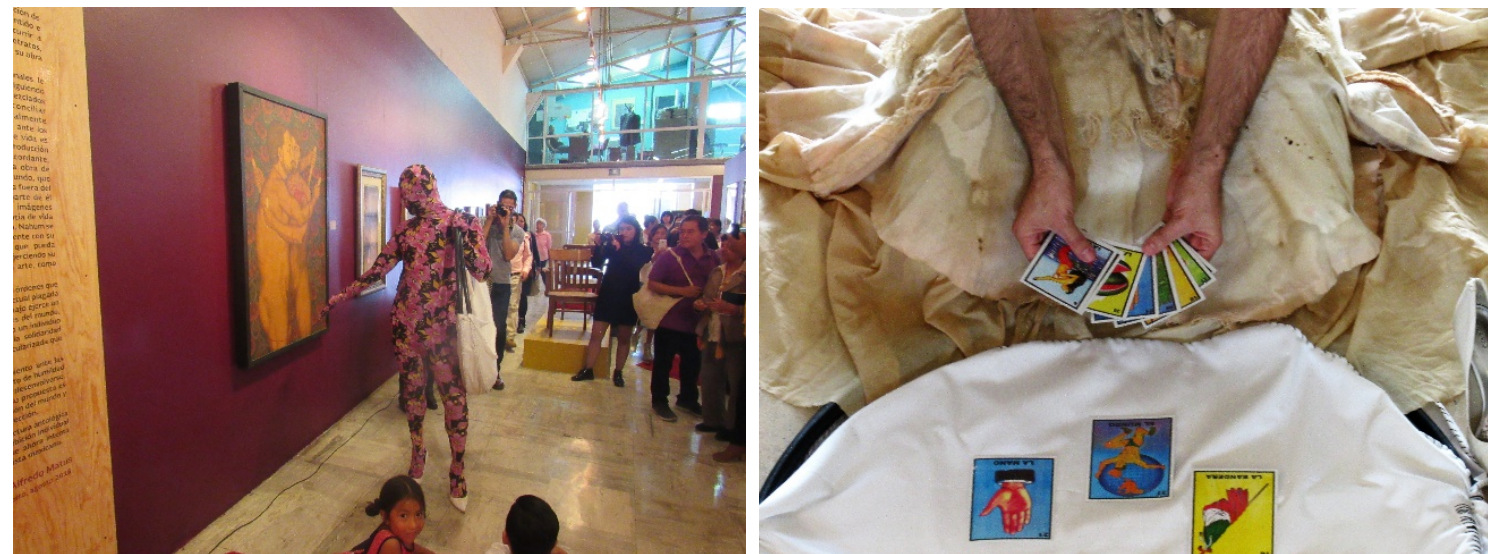

Fonte: Arquivo de Odailso Sinvaldo Berte

Ao som da música Felicidade (Suba/Juryman mix), que se repetia durante toda a execução da obra, o público via uma figura humana coberta com uma pele/malha florida (Figura 4), sem rosto e sem traços genitais (como um manequim), usando sapatos de salto alto e uma bolsa feminina de formato arredondado, de tamanho maior que o normal, que adentrava o espaço sem anúncio, com um andar feminino, desfilando entre as pessoas. Ela/ele interagia sem falar, gerando desconfiança, fascínio, curiosidade e receios nos espectadores. Na Figura 4, vestida com a pele/malha florida (inspirada na obra El hombre tatuado, 1998, de Zenil), a figura humana aparece desfilando pelo espaço da exposição 44. Nahum B. Zenil: alquimista de estereotipos, na Galería José María Velasco, Cidade do México, interagindo com as obras e com o público que reagia de distintas maneiras, surpreendendo-se, rindo e fotografando.

Em um dado momento ela/ele parou, largou sua bolsa, tirou os sapatos e se despiu da pele/malha florida, revelando seu rosto e corpo masculinos e o collant, cinta e outros elementos que moldavam sua anatomia física para aparentar a forma feminina. Ela/ele - que sou eu - ajoelhei-me diante da bolsa e retirei dela uma saia semelhante a uma saia de tehuana, envelhecida e sem cor, a qual vesti retirando, também de dentro da bolsa, as cartas da loteria mexicana (Figura 5). Sobre a bolsa - que virou um tabuleiro - abri as cartas como se fosse um baralho de tarô e do peito, por baixo do collant, tirei a carta 28 - El Corazón, colocando-a 
no centro do tabuleiro entre as outras cartas, como que abrindo minha vida, meus afetos, e lançando-os à sorte do olhar do público.

Na sequência, com outro conjunto de cartas que repetia as mesmas expostas no tabuleiro, me aproximava do público embaralhando as cartas e as oferecia, viradas, para que alguém sorteasse uma. A carta sorteada indicava o conjunto de movimentos/ações a ser performado. Ao todo eram 10 cartas com seu respectivo conjunto de movimentos/ações, cada um com duração de 3 a 5 minutos. A depender do espaço físico e da ocasião da apresentação, se sorteavam de quatro a seis cartas. Embora cada 'carta-movimentos/ações' tivesse uma estrutura/roteiro definido, ou seja, não era improvisação, a estrutura geral da obra - a ordem das 'cartas-movimentos/ações' - mudava em cada apresentação, pois dependia do acaso estabelecido pelo jogo em que o público participava ao sortear a carta.

Figuras 6 e 7 - Tú, él, nosotros tres, 2018, Galería José María Velasco, Cidade do México
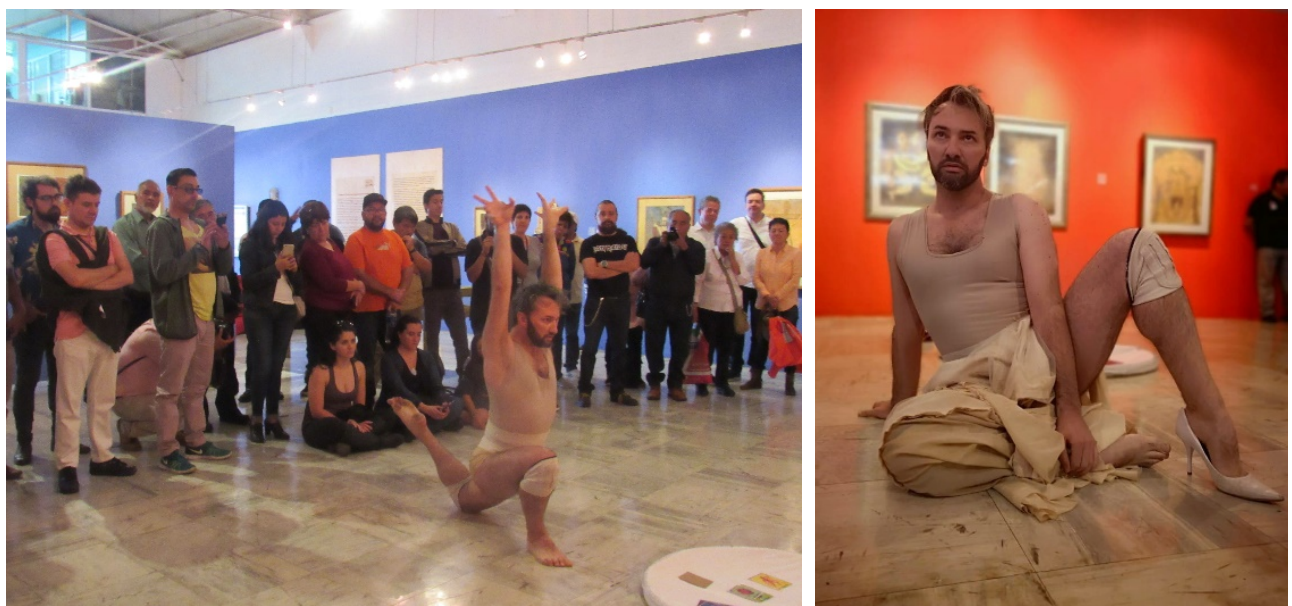

Fonte: Arquivo de Odailso Sinvaldo Berte

O ato de aproximação entre o bailarino-performer e o público, para o sorteio das cartas, constrangia algumas pessoas, enquanto outras, ao compreender a dinâmica da obra durante sua execução (pois nada era anunciado ou explicado antes), entusiasmavam-se com o jogo, ansiosas para ver que carta sairia e como seria seu respectivo conjunto de movimentos/ações. Na Figura 6 executo o conjunto de movimentos/ações da carta 45 - El Venado, esculpindo o movimento 
com formas que aludem ao esbelto animal e também aos sentimentos provocados pelas obras La Venadita de Kahlo e San Sebastián de Zenil. Na Figura 7, referente ao conjunto de movimentos/ações da carta 48 - La Chalupa, usando a saia e apenas um sapato, encaro o público em alusão aos autorretratos de Kahlo, à sua perna curta que interferia em seu movimento, à sua coluna machucada e à sensualidade de seus modos de posar e se portar que, muitas vezes, ocultavam suas dores.

Embora os conjuntos de movimentos/ações relativos às cartas estivessem predefinidos, em cada uma das três apresentações ${ }^{19}$ estes foram se mostrando flexíveis, adaptáveis e mutáveis. Cada espaço, ocasião e conjunto de pessoas acabaram por interferir na construção desses movimentos/ações e modifica-los através das condições de proximidade/distância, ampliação/contenção, aceitação/estranhamento, duração/redução. Os conjuntos de movimentos/ações acabaram sendo constantemente experimentados e reestudados, de modo que o processo criativo permanecia em aberto, lidando com essas interferências, reações e condições estabelecidas a cada realização da obra. E assim ainda o segue, nos estudos e experimentações que sigo projetando e desenvolvendo.

O processo criativo possibilita a reconstituição da autobiografia, ou, nas palavras do neurocientista Damásio (2009, p. 224), do “eu autobiográfico", que é baseado na memória, nas projeções de futuro e nas imagens mentais criadas a partir das nossas interações com mundo. Ao impelir-me a acessar registros pessoais que se explicitam em imagens mentais/afetivas reconstituídas, através do encontro-evento e da fascinação com as imagens artefatos culturais (de Kahlo, Estrada, Zenil e da loteria mexicana), o processo criativo de Tú, él, nosotros tres possibilitou-me reconstituir traços de experiências vividas em relação à perda prematura de minha mãe, à identidade afetiva-sexual e ao fato de (re)conhecerme em terra estrangeira. Essas são questões pessoais e políticas ao mesmo tempo, pois construção de identidade, territorialidade e diferença dizem respeito à vida e à cidadania de muitos sujeitos em suas diversas situações socioculturais.

19 Tú, él, nosotros tres foi apresentada na Galería José María Velasco, nas atividades educativas e acadêmicas da exposição 44. Nahum B. Zenil, alquimista de arquetipos, em 13 de outubro de 2018; no Centro Cultural Brasil-México, em 24 de outubro de 2018; e no Centro Cultural España/México, em 7 nov. 2018. 
O subjetivo/pessoal/individual não está apartado do social/cultural/histórico/político, ele se constitui nesse indissociável enlace corpopsique-tempo-espaço.

Enquanto corpo-artista-pesquisador que faz uso da abordagem metodológica da bricolagem - esta compreendida dentro do conjunto da pesquisa qualitativa (Denzin; Lincoln, 2010), da compreensão de ciência pós-moderna (Santos, 2009; 2010), e da pesquisa narrativa e histórias de vida (Martins; Tourinho; Souza, 2017) - não trato minha criação/pesquisa como sendo de outro, pois não me entendo como sujeito apartado do seu objeto de estudo. Nesse sentido, a reflexão acerca desse objeto de estudo, feita na relação direta com ele, visa romper com o sujeito neutro da ciência moderna em suas análises de sobrevoo, explicitando uma performatividade crítica e criativa do corpo-pesquisador que se reconhece no seu fazer e na reflexão que produz sobre isso.

Considero o processo criativo de Tú, él, nosotros tres um espaço-fronteiriço matricial pelos modos como possibilitou (m)eu corpo tocar em perdas, traumas, fantasias, memórias e experiências vividas não de forma idealista, imaginária ou terapêutica, mas com a consciência de que estas implicam em questões socioculturais e com o afinco artístico de construir uma obra. Com Ettinger (2009), compreendo a obra de arte não como objeto, mas como "transjeto" (Ettinger , 2009, p. 11), um demarcador sociocultural que transcende o processo individual do artista, pois, junto da marca autoral deste estão os vestígios dos demais corpos que compõem essa rede copoiética. Ao tornar-se pública, a obra - transjeto abrese a que outros corpos estabeleçam com ela seus encontros-eventos, dando sentidos, interpretando, identificando-se e reiterando assim a vocação transafetiva dessa esfera matricial. E aqui abre-se um caminho para o prosseguimento desta ou para outra pesquisa dedicada à recepção da obra de arte sob a luz do espaçofronteiriço matricial, baseada em dados provindos dos sujeitos espectadores, o que, no momento, embora reconheça a relevância disso, não é meu foco de estudo. 


\section{O que pode o processo criativo como espaço-fronteiriço matricial}

Com o estudo de elementos do processo criativo da obra de dança performativa Tú, él, nosotros tres e com a relação entre as compreensões da criação como rede em processo (Salles) e do espaço-fronteiriço matricial (Ettinger), percebo o processo de criação como um espaço entrelaçado, fronteiriço e em movimento que, ao mesmo tempo em que é moldado pelo corpo-criador, também molda esse sujeito. Considero o processo de criação em sua espacialidade relacional, ou seja, como "ambiente que se caracteriza pela flexibilidade, não fixidez, mobilidade e plasticidade", instaurado por meio "das interações, dos laços, da interconectividade, dos nexos e das relações" (Salles, 2006, p. 19 e 24). Continuidade, expansão, permeabilidade e conectividade de/em outros corpos são características desse conjunto de (rel)ações transformadoras onde o/a criador/a - corpo-psique-espaço-tempo - trabalha transpassado/a por transafecções diversas, advindas dos enlaces entre sua autobiobrafia, seu contexto sociocultural e a rede copoiética da qual faz parte.

Com Ettinger (2006) e sua perspectiva do espaço-fronteiriço matricial, podemos compreender a/o "artista como obra atravessada por traços vindos de outras pessoas a quem ela está ligada de maneira fronteiriça” (Ettinger, 2006, p.196 - tradução nossa) ${ }^{20}$, como "uma transubjetividade fragmentada, parcial e entrelaçada" (Ettinger, 2006, 197- tradução nossa) ${ }^{21}$. Como a obra que cria, o/a próprio/a artista é (re)criado/a dentro desse útero metafórico, esse espaçofronteiriço matricial que é o processo de criação. Com o processo criativo de Tú, él, nosotros tres redescubro-me como homem-pesquisador-artista que, ao compartilhar com mexicanos, elementos de sua autobiografia e de sua brasileira visão acerca de obras e artistas mexicanos, se vê desafiado a romper com a imagem-tropo mítico de Kahlo e outros artistas, encontra outras formas de viver a ausência do afeto materno, e entende o feminino como constituinte de sua

\footnotetext{
20 [...] the artist as working-through traces coming from others to whom she is border-linked.

${ }^{21}[\ldots .$.$] a fragmented and partial interlaced transsubjectivity.$
} 
masculinidade.

Em sintonia com Salles (2017, p. 45), considero os "processos de criação também como percursos de constituição da subjetividade". No caso do processo criativo da dança performativa, o próprio corpo-artista é sujeito e matéria-prima que vai sendo moldado por essa esfera-fronteiriça matricial que incide na reconstituição de sua autobiografia por meio da investigação do movimento/ação emergida da relação corpo e imagem. O processo criativo é palco/laboratório/útero - espaço-tempo dessa interação densa, dessa cotransformação em que obra e artista, criador/a e criação são (re)concebidos.

\section{Referências}

BERTÉ, Odailso. El abrazo de amor de Kahlo, Estrada, Zenil y yo: una genealogía matrizal desde el cuerpo performativo. México: Universidad Iberoamericana Ciudad de México/Editora UFSM, 2020.

BERTÉ, Odailso. O movimento criativo e pedagógico de Frida Kahlo. Santa Maria: Editora UFSM, 2018.

BERTÉ, Odailso. Dança contempop: corpos, afetos e imagens (mo)vendo-se. Santa Maria: Editora UFSM, 2015.

CORDERO, Karen. My Dress Hangs Here (1933-1938). In: HURTADO, Flor et al. Frida Kahlo 1907/2007. México: Instituto Nacional de Bellas Artes, 2008, p. 144-149.

DAMÁSIO, Antonio. O mistério da consciência: do corpo e das emoções ao conhecimento em si. São Paulo, Brasil: Companhia das Letras, 2009.

DEBROISE, Olivier. Haciéndola cardíaca: para una cultura de los desencuentros y el malentendido. In: SUSSMAN, Elisabeth. El Corazón Sangrante. Boston, First University of Washington Press/The Institute of Contemporary Art, 1991, p. 12-60.

DENZIN, Norman K.; LINCOLN, Yvonna S. (Orgs.). O planejamento da pesquisa qualitativa: teorias e abordagens. Porto Alegre: Artmed, 2010.

ECKMANN, Teresa. ¿Centro o periferia? Frida Kahlo, Neomexicanismo y género. In: LEON, Luis Miguel; ORTEGA, Josefa. ¿Neomexicanismos? Ficciones identitarias en el género de los ochenta. México: Museo de Arte Moderno, 2011, p. 127-144. 
ETTINGER, Bracha Lichtenberg. The Matrixial Borderspace. Minneapolis, Estados Unidos: University of Minnesota Press, 2006.

ETTINGER, Bracha Lichtenberg. Copoiesis. Ephemera| The Jump, or, What is Art? theory \& politics in organization, volume $5(X), 2005$, p. 703-713. Disponível em: http://www.ephemerajournal.org/sites/default/files/5-Xettinger.pdf. Acesso em: 05 abr. 2020.

ETTINGER, Bracha Lichtenberg. Fragilization and Resistence. Studies in the Maternal, 1 (2). Inglaterra: Open Library of Humanities, 2009, p. 1-31. Disponível em: www.mamsie.bbk.ac.uk. Acesso em: 05 abr. 2020.

GREINER, Christine; KATZ, Helena. Corpo e processos de comunicação. In: Revista Fronteiras: estudos midiáticos. São Leopoldo: UNISINOS, v. 3, n. 2, 65-dez, 2001.

KAHLO, Frida. El diário de Frida Kahlo: una nueva mirada. MADRAZO, Claudia. (Ed.). México: La Vaca Independiente, 2017.

KAISER, Rubli (coord.). La Casa Azul de Frida. Cidade do México: Chapa Ediciones, 2007.

KINCHELOE, J. L.; BERRY, K. Pesquisa em educação: conceituando a bricolagem. Porto Alegre: Artmed, 2007.

MARTINS, Raimundo; SÉRVIO, Pablo. Polêmicas e indagações acerca de classificações da cultura: alta, baixa, folk, massa. In: Visualidades: revista do Programa de Pós-Graduação em Arte e Cultura Visual da UFG. v. 10, n. 01, p. 129149. Jan-Jun. Goiânia, 2012.

MARTINS, Raimundo; TOURINHO, Irene; SOUZA, Elizeu Clementino de (orgs.). Pesquisa narrativa: interfaces entre histórias de vida, arte e educação. Santa Maria: Ed. da UFSM, 2017.

POLLOCK, Griselda. Inscripciones en lo feminino. In: GUASCH, Anna María. (Ed.). Los manifiestos del arte posmoderno: textos de exposiciones 1980-1995. Madrid: Ediciones Akal, 2000, p. 322-346.

RENGEL, Lenira. Os temas de movimento de Rudolf Laban: modos de aplicação e referências. São Paulo: Annablume, 2008.

RIVERA, Diego. Frida Kahlo y el arte mexicano. In: LOZANO, Luis-Martín. (Coord.), Frida Kahlo. México: Landucci, 2007, p. 233-235.

SALLES, Cecilia Almeida. Processo de criação em grupo: diálogos. São Paulo: Estação das Cores e Letras, 2017.

SALLES, Cecilia Almeida. Redes da criação: construção da obra de arte. São Paulo: 
Horizonte, 2006.

SANTOS, Boaventura de Souza. Introdução a uma ciência pós-moderna. Rio de Janeiro: Graal, 2010.

SANTOS, Boaventura de Souza. Um discurso sobre as ciências. São Paulo: Cortez, 2009.

TIBOL, Raquel. Arturo Estrada y sus caminos en el Arte Mexicano (versão reproduzida pela família de Arturo Estrada). México: Instituto Nacional de la Juventud Mexicana / Ciclo Presidente López Mateos, 1961.

TOURINHO, Irene; MARTINS, Raimundo. Circunstâncias e ingerências da cultura visual. In: MARTINS, R.; TOURINHO, I. (Orgs.). Educação da cultura visual: conceitos e contextos. Santa Maria, RS: Editora da UFSM, 2011, p. 51-68.

Recebido em: 05/05/20

Aprovado em: 16/07/2020 